\title{
レーザーオリジナル
}

\section{Two-stage Blumlein回路を用いた窒素レーザー}

\section{吉川 晃*・宮 沢 まゆみ*}

(1984年 9 月26日 受理)

\section{Nitrogen Laser pumped with Two-stage Blumlein Circuit}

\author{
Akira YOSHIKAWA* and Mayumi MIYAZAWA*
}

(Received September 26, 1984)

\begin{abstract}
In order to obtain effective pumping of the $\mathrm{UV} \mathrm{N}_{2}$ laser, a newly modified Blumlein circuit named Two-stage Blumlein (TB) has been proposed; after the circuit analysis, we designed the TB circuit. Compared with the conventional Blumlein circuit, the TB gives a faster rising discharge current, though it needs an additional set of a spark gap and a charging capacitor; by the use of a $25 \mathrm{~cm}$ in length laser tube, the output energy by the TB has been about twice as large as the conventional one.
\end{abstract}

\section{1．まえがき}

窒素レーザーは製作が容易であり，しかも強 力な紫外光パルス（主に337.1 nm）が得られる ため, 励起光源としての応用範囲は広い。この レーザーは, $C^{3} \pi_{u}$ から $B^{3} \pi_{8}$ への second positive bandの電子遷移により発振するが, $C^{3} \pi_{8}$ の短い lifetime (約 $40 n \mathrm{sec}$ )に比べ $B^{3} \pi_{\boldsymbol{g}}$ の life-

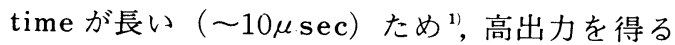
には立上りの早いパルス励起を行う必要がある。 この目的にかなったものとして Blumlein 型放 電回路がある ${ }^{2}$ 5)。この回路の特徵は, レーザ 一管の両側に取付けた充電用コンデンサーの一 方を放電させ，その電圧反転によってレーザー 電極間に充電電圧の 2 倍の電倍差を生じさせる 点にあるる。の高電位差の下でレーザー管内に は立上りの早い放電が実現される。
我々が考案したTwo-stage Blumlein型(以 後 TB型と略す) 放電回路とは, 従来の Blumlein 型回路のスパークギャップをもう 1 つの Blumlein 回路を使って起動させるもので, Blumlein 回路を 2 段階に動作させるのでこ の名をつけた。Fig. 1 (a)にTB回路の概略を示 す。この回路の動作は, キャパシタンス, イン ダクタンスなどの回路定数, 第 1 のスパークギ ヤップG $G_{1}$ が放電してから第 2 のスパークギャッ プ $G_{2}$ が放電するまでの遅れ時間，および $G_{2}$ が 放電してからレーザー管が放電するまでの遅れ 時間により变化する。我々は, Fig.1(b)の等価 回路を用いて，レーザー管内に流れる電流の立 上りが,この放電の遅れ時間と回路定数にどの ように依存するかを計算した。その結果，ある 条件（後に詳述）が満たされればレーザー管の 電極間には充電電圧の 3 倍以上の電位差が生じ,

* 山梨大学教育学部 (₹ 400 甲府市武田四丁目 4-37)

* Faculty of Liberal Art and Education, Yamanashi, University-(4-4-37, Takeda, Köhu, 400) 


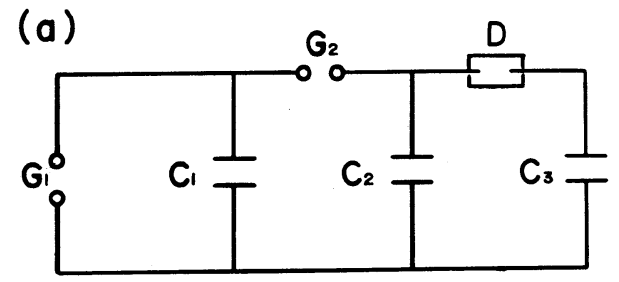

(b)

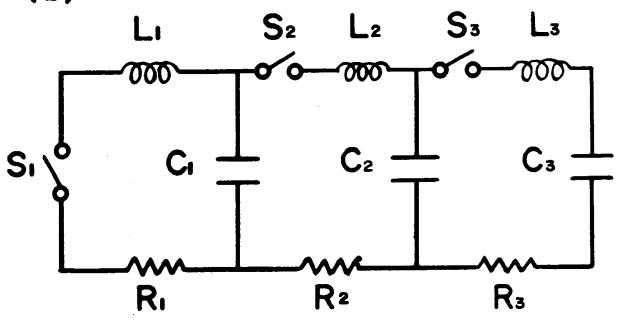

Fig. 1 (a) Schematic represantation of a Twostage Blumlein laser system and (b) its equivalent circuit.

従来のBlumlein型回路よりも鋭い立上りの放 電が行われるはずという結論を得た。この計算 結果をもとに, T B型窒素レーザーを試作し, その出力特性を調べたところ,従来のBlumlein 型回路を上回る出力が確認された。本論文では まず T B型回路の根拠となる回路計算を示し， つぎに試作した T B 型窒素レーザーの出力特性 について述べることにする。

\section{2. 計算結果}

Blumlein型窒素レーザーの数值解析に関する 研究は, $\mathrm{Gerry}^{6)}, \mathrm{Ali}^{7)}$, 野村等 ${ }^{8)}$ によってなさ れている。それによると, 窒素レーザーの高出 力化にとって重要なポイントは, レーザー管内 での放電電流の立上りをいかに早くするかとい うことである。したがって, 窒素レーザーにと つて好ましい回路とは, 電流の立上りの早い回 路である。この点を考虑し，ここでは主として 電流の立上りについての計算を行い, その結果 をもとに TB回路と Blumlein 回路の性能比較, および $\mathrm{T} \mathrm{B}$ 回路を有効に動作させる条件につい ての検討を行う。

Fig. 1(b)は, 我々が計算を行った T B 回路 の等価回路である。この回路の特徴は, $G_{1}, G_{2}$
とレーザー管をスイッチ $S_{1}, S_{2}, S_{3}$ に置き換 えたことである。遅れ時間の影響を調べるには $S_{1}$ onから $S_{2}$ onまでの時間, 更に $S_{2}$ onから $S_{3}$ onまでの時間を变えて計算を行なえばよい。 つぎに計算の手順を示す。

任意の時間にコンデンサー $C_{1}, C_{2}, C_{3}$ に貯 えられている電荷を $Q_{1}, Q_{2}, Q_{3}$ とすれば, こ れらに対して次の回路方程式が成り立つ。

$$
\begin{aligned}
& L_{1} \frac{\mathrm{d}^{2}}{\mathrm{~d} t^{2}}\left(Q_{1}+Q_{2}+Q_{3}\right)+R_{1} \frac{\mathrm{d}}{\mathrm{d} t}\left(Q_{1}\right.\left.+Q_{2}+Q_{3}\right) \\
&+\frac{Q_{1}}{C_{1}}=0 \\
& L_{2} \frac{\mathrm{d}^{2}}{\mathrm{~d} t^{2}}\left(Q_{2}+Q_{3}\right)+R_{2} \frac{\mathrm{d}}{\mathrm{d} t}\left(Q_{2}+Q_{3}\right)+\frac{Q_{2}}{C_{2}}=\frac{Q_{1}}{C_{1}}(1) \\
& L_{3} \frac{\mathrm{d}^{2}}{\mathrm{~d} t^{2}} Q_{3} R_{3} \frac{\mathrm{d}}{\mathrm{d} t} Q_{3}+\frac{Q_{3}}{C_{3}}=\frac{Q_{2}}{C_{2}}
\end{aligned}
$$

なお，上式を導くにあたり各コンデンサーに 流れる電流 $I_{1}, I_{2}, I_{3}$ は

$$
I_{1}=\frac{\mathrm{d} Q_{1}}{\mathrm{~d} t}, \quad I_{2}=-\frac{\mathrm{d} Q_{2}}{\mathrm{~d} t}, \quad I_{3}=-\frac{\mathrm{d} Q_{3}}{\mathrm{~d} t}
$$

のように定義した。

最初 $C_{1}, C_{2}, C_{3}$ は等しい電位に充電されて いるものとする。この時, スイッチは全部開い ているが， $t=0$ においてまず $S_{1}$ を閉じ，つぎ に $t=\tau_{1}$ において $S_{2}$ を, $t=\tau_{1}+\tau_{2}$ において $S_{3}$ を閉じるものとする。すなわち， $\tau_{1}$ は $G_{1}$ が放 電してから $G_{2}$ が放電するまでの遅れ時間， $\tau_{2}$ は $G_{2}$ が放電してからレーザー管が放電するまで の遅れ時間に対応する。回路定数と $\tau_{1}, \tau_{2}$ を変 化させて上の方程式を解いた結果をつぎに示す。

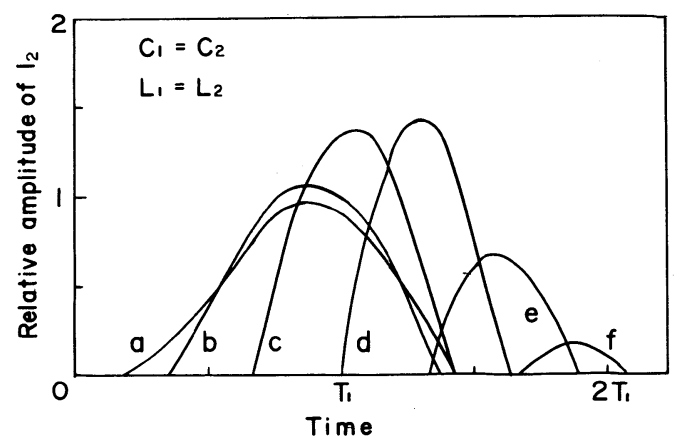

Fig.2 Time behaviour of the current $I_{2}$ flowing from $C_{2}$ after $S_{2}$ is closed at (a) $t=0$, (b) $t=(1 / 3) T_{1}$, (c) $t=(2 / 3) T_{1}$, (d) $t=T_{1}$, (e) $t=(4 / 3) T_{1}$ and $(\mathbf{f}) t=(5 / 3) T_{1}$. 


\section{1 $I_{2}$ に及ぼす $\tau_{1}$ の影響}

Fig. 2 に $I_{2}$ の時間変化を示す。ただし，ここ では議論を簡単にするため, $R_{1}=R_{2}=R_{3}=0$, $C_{1}=C_{2}=C_{3}, L_{1}=L_{2}=L_{3}$ とした。横軸は $S_{1}$ を閉じてからの経過時間を表わし，単位は $C_{1}$ の電圧反転時間 $T_{1}=\pi \sqrt{L_{1} C_{1}}$ をとった。各曲線 は， $\tau_{1}$ を変化させた場合の $I_{2}$ のグラフを表わし ている。これより， $\tau_{1}$ をきくしていくと電流 の立上りは次第に早くなり， $\tau_{1}=T_{1}$ 付近で 最 大值をとることがわかる。 $C_{1}$ の電圧反転が完了 するのは $\tau_{1}=T_{1}$ の時であり, この時 $S_{2}$ の両端 の電位差は最大値（充電電圧の 2 倍）をとる。 したがって,この計算結果は, 高い電位差での 放電ほど立上りが早くなることを裏付けている。 ところで， $S_{1}$ をスパークギャップ， $S_{2}$ をレーザ 一管とみなせば, これは従来の Blumlein 回路 に対応しており，いままでのレーザーでも放電 の遅れ時間がレーザー出力を左右する重要な要 素であることがわかる。

\section{$2.2 I_{2}$ と $C_{2}$ の反転電位に及ぼす $C_{1}$ の影響}

計算の結果, $C_{1}$ の容量を変えても $I_{2}$ が $\tau_{1}$ に依 存する様子は, Fig. 2 と基本的には変わらない ことがわかった。すなわち， $C_{1}$ の電圧反転が完 了する時点で $S_{2}$ を閉じれば $I_{2}$ の立上りは早く なるが，前後に時間がずれるほど立上りは低下 する。ただし， $C_{1}$ を変えれば反転時間も変わる ので, $\tau_{1}$ の值はそれに応じて適当に選ぶ必要が ある。Fig. 3 は，さまざまな $C_{1}$ に対し $I_{2}$ の立上

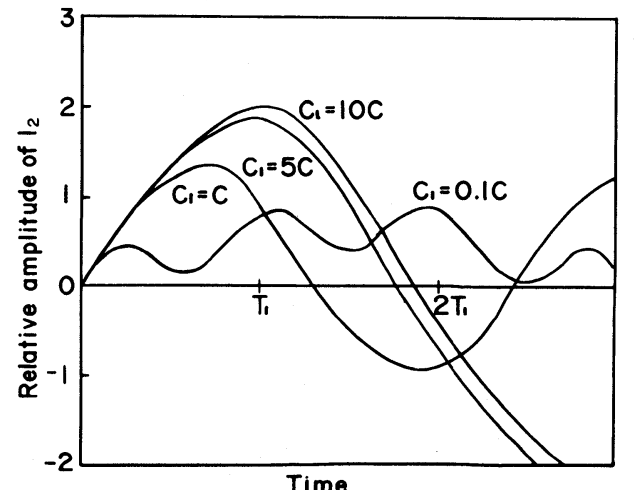

Fig. 3 Time behaviour of $I_{2}$ when $S_{2}$ is closed just before the voltage of $C_{1}$ is reversed owing to $L C$ oscillation.
りが最大になるように $\tau_{1}$ を選んだ時の $I_{2}$ の時間 変化である。グラフの中で $C_{1}=10 C, 5 C, C$, $0.1 C$ とあるのは, $C_{1}$ の容量が $C_{2}, C_{3}$ の10倍, 5 倍, 1 倍, 0.1 倍であることを意味する。 $\left(C_{2}\right.$ $=C_{3}=C$ とした）横軸は $S_{2}$ を閉じてからの 経 過時間を表わしており, 全ての曲線が原点から 始っているのはこのためである。このグラフか ら次のような特徵を見ることができる。

(1) $S_{1}$ を閉じた直後の $I_{2}$ の立上りは， $C_{1}$ の容量 を変えても殆んど変化しない。

(2) $I_{2}$ は $C_{1}$ の容量が小さい程, 早くピーク値に 達する。また, このピーク值は $C_{1}$ が大きい程 大きな値になる。

まず，(1)に関して考えてみる。先に述べたよ うに，窒素レーザーにおいてレーザー出力に影 響を与えるのは，主に電流の立上り特性であっ て, 電流の絶対值ではない。したがって,(1)の 性質はBlumle in回路においてギャップ側のコン デンサーの容量を変えてもレーザー出力は変化 しないことを意味する。しかし， $C_{1}=0.1 C$ の グラフからわかるように，C $C_{1}$ 小さくしすぎる と初期電流の絶対值が小さくなりすぎるので, レーザー出力は減少するであろう。また， $C_{1}$ を 大きくした場合は $C_{1}$ の反転時間が長くなり過ぎ, 反転が完了する以前に放電が開始するので, や はりレーザー出力は減少するであろう。実際の 回路において $C_{1}$ の容量に適当な值があるのも, こういった点から理解できる。

つぎに(2)に関してであるが， $I_{2}$ が正であるこ とは $C_{2}$ から $C_{1}$ に向って電流が流れることを意 味する。したがって， $C_{1}$ を大きすると $I_{2}$ が大 きくなるという計算結果は， $C_{1}$ を大きするこ とによって $C_{2}$ の反転電位が大きくなることを意 味する。 (Fig. 3 の各曲線の正の部分を積分し た値が $C_{2}$ の反転電位に比例する。） $C_{1}=C$ の場 合, $C_{2}$ が到達する反転電位は充電電圧の 1.1 倍 である。ところが, $C_{1}=5 C, C_{1}=10 C$ の時の 反転電位は, 各々, 充電電圧の 2.1 倍, 2.3 倍と なる。したがって, この場合には $S_{3}$ の両端には 充電電圧の 3 倍を越える電位差が生じるので, この瞬間に $S_{3}$ を閉じるならば, $I_{3}$ の立上りは非 


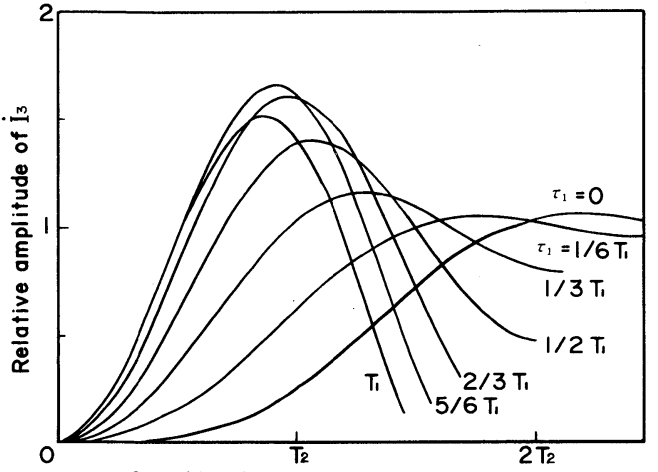

Switching interval between $S_{2}$ and $S_{3}$

Fig. 4 Characteristic curves showing the ris ing of the current $I_{3}$ on the switching delay times $\tau_{1}$ (between $S_{1}$ and $S_{2}$ ) and $\tau_{2}$ (between $S_{2}$ and $S_{3}$ ).

常に早くなるはずである。T B回路の理論的根 拠はこの点にある。

\section{$2.3 I_{3}$ に及ぼす $\tau_{1}, \tau_{2}$ の影響}

ここでは， $S_{3}$ を閉じた直後の $I_{3}$ の立上り（以 後, この值を $\dot{I}_{3}$ と表示する）が, $\tau_{1}, \tau_{2}$ によっ てどのように変化するかを見ることにする。

Fig. 4 に $C_{1}=5 C, C_{2}=C_{3}=C, R_{1}=R_{2}=R_{3}$ $=0, L_{1}=L_{2}=L_{3}$ の場合のグラフを示す。縦軸 は $\dot{I}_{3}$ を表わし, 単位は $C_{1}$ の電圧反転が完了した 直後の $\dot{I}_{2}$ の值 (これはBlumlein回路における電 流の立上りの最大值とみなせる。）を 1 としてい る。横軸は $\tau_{2}$ をとり，単位は $T_{2}=\pi \sqrt{L_{2} C_{2}}$ を 用いた。 $T_{2}$ は $L_{2} C_{2}$ 回路が独立に存在した場合 の反転時間を表わす。

まず $\tau_{1}=0$ の場合, $\tau_{2}$ を増すと $\dot{I}_{3}$ はゆるやか に増加し， $\tau_{2}$ が2.2 $T_{2}$ のところでピーク值 1.0 を持つ。この場合は, ギャップ側のコンデンサ 一容量が $C_{1}+C_{2}=6 C$ の Blumlein回路として 動作させたとみなせる。 $\tau_{1}$ を増やして $\tau_{1}=T_{1}$ $/ 2$ にした場合は, $\dot{I}_{3}$ のピーク值は 1.4 と増加し, この時の $\tau_{2}$ の值は $1.1 T_{2}$ となって, ほぼ $C_{2}$ の 反転時間に一致する。更に $\tau_{1}$ を増やすと， $\tau$, $=5 / 6 T_{1}$ の時に $\dot{I}_{3}$ は最大值 1.65 をとる。この時の $\tau_{2}$ の值は $0.9 T_{2}$ である。したがって, T B回路 を動作させるには， $C_{1}$ の電圧反転が完了する少 し前に $S_{2}$ を閉じるのが理想的であるといえる。
いずれにしても，これによって T B 回路が Blumlein回路よりも電流の立上りの早い回路で あることが明らかとなった。

\section{$2.4 I_{3}$ に及ぼす $C_{1}, R_{1}, R_{2}$ の影響}

Fig. 5 は， $I_{3}$ が $C_{1}, R_{1}, R_{2}$ に依存する様子を 示したものである。横軸は $C_{2}, C_{3}\left(C_{2}=C_{3}=\right.$ C) に対し $C_{1}$ を変化させた。縦軸は, $\dot{I}_{3}$ が最大 となるように $\tau_{1}, \tau_{2}$ を選んだときの $\dot{I}_{3}$ の值, $\left(\dot{I}_{3}\right)_{\max }$ を表わしている。縦軸の単位は Fig. 4 の場合と同じくBlumlein回路の電流の立上り の最大值を 1 としている。

$$
R_{1}=R_{2}=0 \text { の場合, } C_{1}=C \text { では }\left(\dot{I}_{3}\right)_{\max } \text { は }
$$
Blumlein 回路の場合と殆んど変わらないが, $C_{1}$ を增すと増加し,$C_{1}=3 C$ では 1.4 を越え， $C_{1}=10 C$ では 1.7 になる。だし， $C_{1}=10 C$ 付 近では曲線の傾きはゆるやかで，これ以上 $C_{1}$ の容量を増しても電流の立上りは殆んど増加し ない。 $R_{1}, R_{2}$ に抵抗を与えた場合は, 電流の立 上りは減少する。また $C_{1}$ に対する依存性にも変 化がみられ， $C_{1}$ を増しても $\left(\dot{I}_{3}\right)_{\max }$ の増加は小 さく, $C_{1}$ が $5 C$ を越えるとわずかであるが減少 の傾向を見せはじめる。このように， $R_{1}, R_{2}$ のいずれの抵抗が増えても $\dot{I}_{3}$ は減少することが わかった。この原因は次のように考えられる。

$L C$ 回路において貯えられた電荷が抵抗 $R$ を 通して放電する時, 電圧反転までにこの回路で 失われるエネルギーWは, $R \ll \sqrt{L / C}$ の場合に は

$$
W=\frac{C V_{0}^{2}}{2} \pi R \sqrt{\frac{C}{L}}
$$

で表わされる。ここで $V_{0}$ は充電電圧である。こ の式から， $R$ が大きい程， $C$ が大きい程，失わ れるエネルギーは大きくなることがわかる。失 われるエネルギーが大きいと反転電位は小さく なり，これが電流の立上りを低下させると考え れば，上の計算結果は説明できる。

\section{$2.5 \quad L_{1}$ の影響}

Fig. 6 は $L_{1}$ の值をFig. 5 の場合の10倍にした 時のグラフである。その他の回路定数は Fig. 


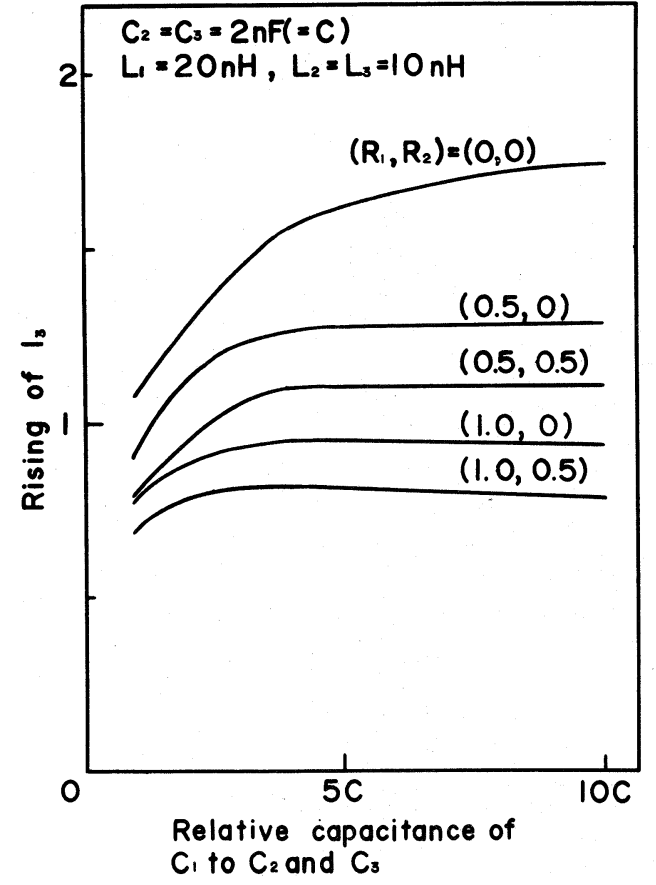

Fig. 5 Dependence of the rising of $I_{3}$ on capacitance of $C_{1}$ in the case of $L_{1}=20 \mathrm{nH}$ and $L_{2}=L_{3}=10 \mathrm{nH}$.

5 の值と同じである。Fig. 5 と比較すると $R_{1}$, $R_{2}$ とも 0 の場合は $\left(\dot{I}_{3}\right)_{\max }$ の值はインダクタン スが変わっても変化しない。ところが $R_{1}=0.5$ $R_{2}=0$ とした場合は, 明らかに Fig. 6 の方が $\left(\dot{I}_{3}\right)_{\max }$ の値は大きくなっている。他の場合も同 様にインダクタンスの大きいFig. 6 の方が電流 の立上りは早くなっている。実際の回路ではス パークギャップ $G_{1}, G_{2}$ の放電抵抗は無視できな いので，この計算結果は回路設計をするうえで 注目すべきである。インダクタンスを増すと電 流の立上りが早くなる結果は, やはり (3)式を使 って説明できる。すなわち, インダクタンスが 増えれば放電抵抗によるエネルギー損失が小さ くなるからである。

\section{6 計算結果のまとめ}

以上の計算結果から, T B 回路を有効に動作 させるための条件は次の 5 つにまとめられる。

（1） 遅れ時間 $\tau_{1}$ を $C_{1}$ の電圧反転時間 $T_{1}$ の 少 し前にセットする。

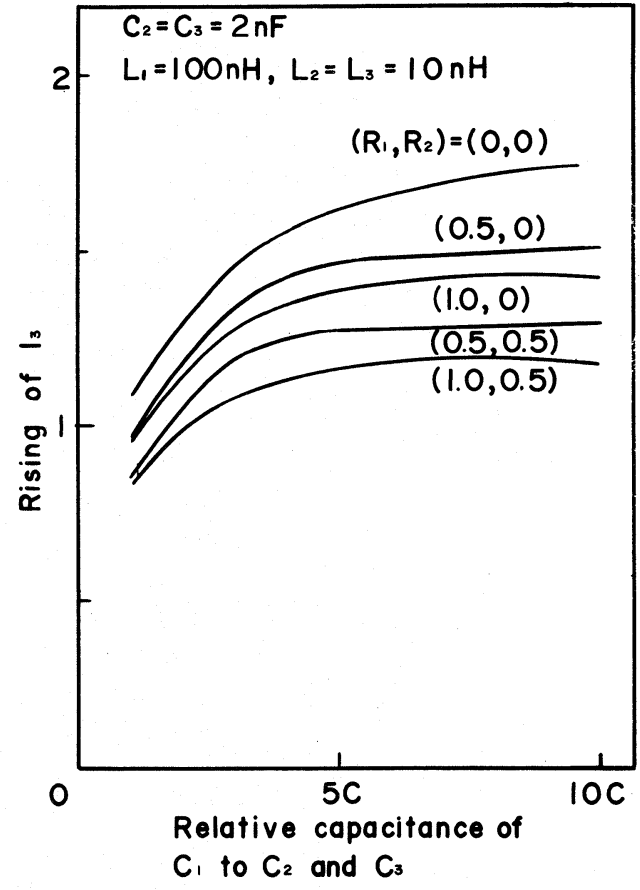

Fig. 6 Dependence of the rising of $I_{3}$ on $C_{1}$ in the case of $L_{1}=100 \mathrm{nH}$ and $L_{2}=L_{3}=10$ $\mathrm{nH}$.

(2) $R_{1}$ を小さくする。

(3) $R_{2}$ を小さくする

(4) $C_{1}$ の容量を $C_{2}$ の 4 〜 倍程度にする。

(5) $L_{1}$ を大きくする。

(2)及び(4)の条件は他の 3 つと独立に考えるこ とができる。しかし，(1)，(3)，(5)は互に密接な 関係がある。すなわち，「L が大きくなる $\tau_{1}$ を大きくしなければならない $\rightarrow G_{2}$ のギャップ間隔を大きくする必要がある $\rightarrow$ 放電抵抗 $R_{2}$ が大きくなる」ということで, (3)と (5)は相反する条件となっている。したがって, $L_{1}$ についても単純に大きくすればよいというの ではなく， $G_{2}$ のギャップ間隔に応じた適当な值 があるはずである。ともかく，上にあげた $5 つ$ の条件は実際の回路を設計するうえで考虑され るべき重要なポイントである。

\section{3. 実験結果}

いままでの計算によって T B回路の有効性が 理論的に示されたので，これを実験的に確かめ 


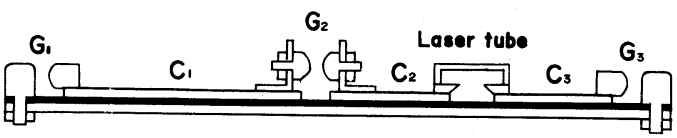

Fig. 7 Schematic repesantation of a nitrogen liser which can be operated with either of the Blumlein circuit and the Twostage Blumlein circuit.

るため Fig. 7 に示す窒素レーザーを製作した。 $C_{1}, C_{2}, C_{3}$ 屿 $0.35 \mathrm{~mm}$ の ネラーシートをアル ミ板ではさんだ平行平板コンデンサーで，その 容量は $C_{1}=19 \mathrm{nF}, C_{2}=C_{3}=3.8 \mathrm{nF}$ である。 $C_{1}$ が $C_{2} ， C_{3}$ の 5 倍になるように設計した。レーザ 一管の放電長は $25 \mathrm{~cm}$, 電極間隔は $12 \mathrm{~mm}$ で, レー ザー管の一方の端にはアルミ蒸着した平面鏡を 取付けた。 $G_{1}, G_{2}, G_{3}$ はスパークギャップで, $G_{1}, G_{2}$ を動作させると T B 回路になり， $G_{3}$ だ けを動作させるとBlumlein回路となる。こうす ることによって，全く同じ条件の下で 2 つ回 路の性能を比較できる。ところで， T B 回路を 有効に働かせるには $\tau_{1}$ が最適な值をとることが 必要で放る。これを実現するには， $G_{2}$ の間隔を 変えて放電の遅れ時間を調節するのが最も簡単 である。そこで， $G_{2}$ の間隔を $0 〜 4 \mathrm{~mm}$ まで 5 段 階に変えつつ, 供試電圧 $15 \mathrm{kV}$ の下でレーザーエ ネルギーを測定した。その結果を F ig. 8 に示す。 5 本の実線は T B 回路として動作させた場合の グラフであり, 破線はBlumlein 回路として動 作させたものである。T B 回路として動作させ た場合， $G_{2}$ の間隔によってレーザーエネルギー は大きく変化する。まず $G_{2}$ の間隔が $0 \mathrm{~mm}$ のき, レーザーエネルギーはBlumlein回路の場合と 殆んど一致した。ところが $0.8 \mathrm{~mm}$ にするとレー ザーエネルギーは短絡したときよりも低下した。 これは，間隔が狭いときは $\tau_{1}$ が小さいため,

T B回路としての長所が生かされず，むしろ $G_{2}$ の放電抵抗によるエネルギー損失のために出力 が低下したと考えられる。しかし，間隔をもっ と広げていくとレーザーエネルギーは増加し， $1.8 \mathrm{~mm}$ のときは短絡した場合をやや上回り, 3.2 $\mathrm{mm}$ のときは更に増加した。特にガス圧の高い領 域での増加が顕著で, 最大出力が得られるガス

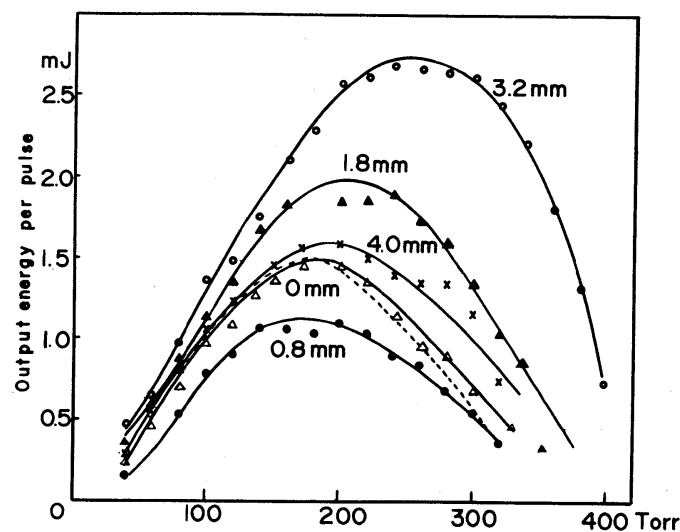

Fig. 8 Dependence of laser output energy on gas pressure. A group of solid lines shows that measured by changing spark gap seperation of $G_{2}$ in the case of the TB circuit and a broken line in the case of the Blumlein circuit.

圧は，短絡した時よりも高圧側にシフトしてい る。レーザー出力を支配する重要なパラメータ 一が $E / p$ であることを考えれば，この場合はレ 一ザー電極間に短絡した時よりも高い電位差が 生じていることになる。これは，T B回路が有 効に動作していることを示している。更に間隔 を $4.0 \mathrm{~mm}$ に広げるとレーザーエネルギーは減少 した。結局, $3.2 \mathrm{~mm}$ の時の出力が最大となり, Blumlein回路の約 2 倍の出力が得られた。この ように，同じレーザー管を使い，スパークギャ ップの形状，充電電圧を等しくして，全く同じ 条件で比較したところ, 従来のBlumlein 回路 の約 2 倍の出力を得たことは, T B 回路の有効 性を明示している。

ところで, TB回路はBlumlein回路に余分な コンデンサー $C_{1}$ を付加するので必然的に大型化 せざるを得ない。 $C_{1}=4 C$ としても，全体の 容 量はB lumlein回路の 3 倍となるので, TB回路 の真の性能を試すには, $C_{2}, C_{3}$ の值が 3 倍の Blumlein回路と比較する必要がある。そこで我 々は,コンデンサーの容量が $0.8 \mathrm{nF}$ を単位とし て何段階にも変えられるレーザーを新しく製作 し，その出力を測定した。Fig. 9 にその結果を 示す。横軸は $C=0.8 \mathrm{nF}$ を単位とした $C_{2}, C_{3}$ の容量を示している。 2 つの曲線のうち下部の 


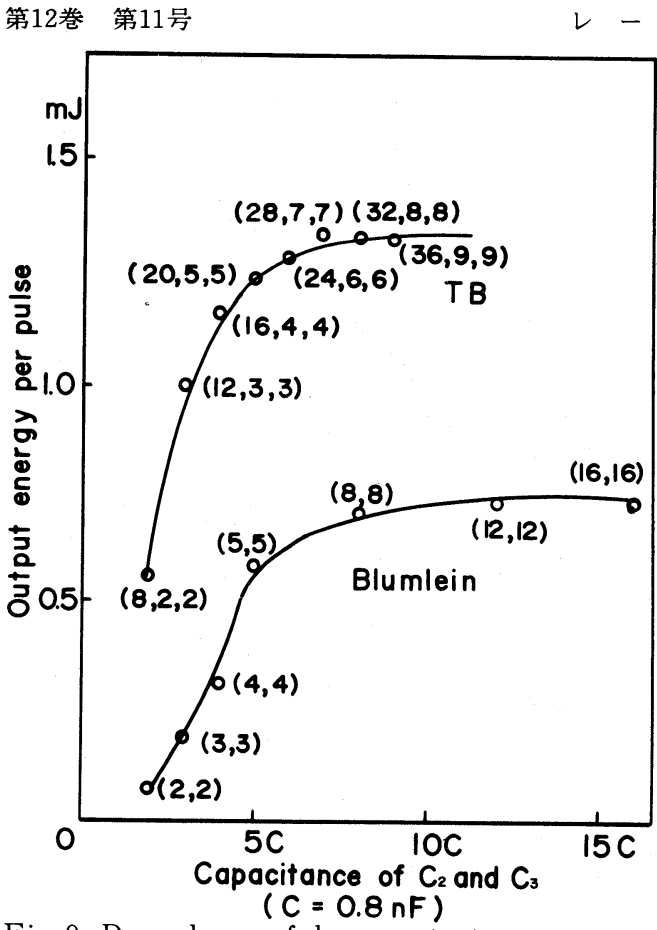

Fig. 9 Dependence of laser output energy on capacitance of $C_{1}, C_{2}$ and $C_{3}$.

ものは従来のBlumlein回路として動作させたも ので, 括弧の中の数字は $C_{2}, C_{3}$ の容量を示して いる。例えば $(6,6)$ の場合, $C_{2}, C_{3}$ の容量 は $0.8 \times 6=4.8 \mathrm{nF}$ である。上部の曲線は， $C_{1}$ の容量を $C_{2}, C_{3}$ の 4 倍にして T B回路として動 作させたものである。どちらの回路においても， $C_{2}, C_{3}$ が小さい時にはコンデンサーの容量を増 せば出力は急激に増加するが， $6.4 \mathrm{nF}$ を越える 付近からは殆んど出力の増加はみられない。飽 和した值を比べると, TB回路の值は Blumlein 回路の約 2 倍となっており, Blumlein回路でい くら大型化しても，T B回路における $(12,3,3)$ の場合の出力を上回れないことがわかった。以 上から，T B 回路はレーザーを大型化せざるを 得ないという難点はあるものの, 高出力を得る にはBlumlein回路よりも優れていることが明ら かとなった。

以上, T B 回路と Blumlein回路の性能を比較 することを中心に話を進めてきたが，我々は他 にも次のような興味ある実験結果を得ている。

(1) $C_{1}$ は $C_{2}, C_{3}$ の 4 倍が適当で, これ以 上大きくしても出力は増加しない。これは計
(650)

算結果とも一致している。

（2）レーザー出力が最大となる時の遅れ時間 $\tau_{1}$ は, 反転時間 $T_{1}$ のおよそ半分で, 計算で予想 したよりもかなり小さくなっている。これは， $\tau_{1}$ を大きくするのに $G_{2}$ の間隔を広げていっ たが，こうすると $G_{2}$ の放電抵抗が大きくなっ て出力が低下したと考えられる。

\section{4. むすび}

これまで，新しい回路である T B 回路の動作 を詳述してきたが，以下にこの回路をより有効 に動作させるための問題点について議論する。

$\mathrm{T} \mathrm{B}$ 回路を動作させるうえで重要な点は, $G_{1}$ が放電してから $G_{2}$ が放電するまでの遅れ時間を $G_{1}$ の電圧反転時間 $T_{1}$ に一致させることである。 ところが実際の回路において出力が最大になる のは， $\tau_{1}$ がおよそ $T_{1} / 2$ の時点であった。 $G_{2}$ の ギャップ間隔を増せば $\tau_{1} も$ 増すが，ギャップで の抵抗増加によるエネルギー損失が $\tau_{1}$ を大きく する効果を打消してしまったと考えられる。し たがって, 遅れ時間が大きく, かつ抵抗の小さ いギャップ $G_{2}$ を夫すればレーザー出力は更に 増大することが期待できる。これを実現する可 能性のあるものとして, 加圧式同軸ギャップが 考えられる。

もう1つの有力な方法は, 多段式レーザーに T B 回路を応用することである。Fig. 9 で見ら れたように，コンデンサーの容量を増してもレ 一ザー出力の増加には限度がある。これを解決 するには，コンデンサーを分割した多段式レー ザーにすればよいが，従来の回路では複数のス' パークギャップを同時または適当な時間間隔で 放電させるのは容易でない。ところが $\mathrm{T} \mathrm{B}$ 回路 を用いれば，これが比較的容易にできるはずで ある。我々の経験によれば, $G_{1}$ と $G_{2}$ の放電間隔 のジッターは極めて小さい。これは $G_{2}$ が $G_{1}$ よ りもギャップ間隔がせまくしかも高電位差の下 で放電するからである。したがって, 複数の $G_{2}$ を持った多段式 T B 型レーザーが有効に動作す る可能性は極めて大きい。

いずれにしても，T B 型回路を工夫して出力 
を増大させる余地はまだ充分にあるものと思わ れる。

\section{参考 文献}

1) Coli: S. Willet: Introduction to Gas Lasers (Pergamon Pres;, 1974) pp.342-357.

2) J. D. Shipman Jr. : Appl. Phys. Lett. 10 (1967) 3.
3) D. Basting, F. P. Schäfer and B. Steyer : Optoelectronics 4 (1972) 43.

4) B. Godard: IEEE J. Quantum Electron. QE-10 (1974) 147.

5) 石田祐三, 矢島達夫：応用物理46（1977） 996.

6) E. T. Gerry: Appl. Phys. Lett. 7 (1965) 6.

7) A. W. Ali : Appl. Opt. 8 (1969) 993.

8) 野村彰夫，斉藤保典，鹿野哲夫：応用物理 52 (1983) 982 . 